\title{
Behçet Hastaları ve Kontrol Grubunda Tüberkülin Deri Testi Sonuçlarının Karșılaștırılması
}

\section{Comparison of the Results of Tuberculin Skin Test in Patients with Behçet's Disease and Control Group}

Nurșad Çifçi Aslan, Dilek Bayramgürler*, Evren Odyakmaz Demirsoy*, Meryem Bakır***, Cavit Ișık Yavuz**, Aysun Șikar Aktürk*, Nilgün Bilen*, Rebiay Kıran*

Gediz Devlet Hastanesi, Deri ve Zührevi Hastalıklar Kliniği, Kütahya, Türkiye *Kocaeli Üniversitesi Tıp Fakültesi, Deri ve Zührevi Hastalıklar Anabilim Dalı, **Halksağlı̆̆ı Anabilim Dalı, ***Gölcük Devlet Hastanesi, Deri ve Zührevi Hastalıklar Kliniği, Kocaeli, Türkiye

\section{Özet}

Amaç: Behçet hastalarında hem immün sistemdeki varolan değișiklikler hem de paterji reaksiyonu nedeniyle pürifiye protein derivesi (PPD) testine yanıtın Behçet hastalığı olmayanlardan farklı alınabileceğini düșünerek bu çalıșmayı planladık.

Gereç ve Yöntem: Bu çalıșmaya 19-44 yaș arası 21 Behçet hastası dahil edildi. Bu hastaların hiçbirisinde kolșisin dıșında sistemik bir ilac kullanımı ya da bașka bir sistemik hastalık öyküsü yoktu. Tüm hastalar kolșisin tedavisi almaktaydı ve BCG așıları pozitifti. Aynı tarihlerde dermatoloji polikliniğine bașvuran, tinea pedis tanısı konulan, sistemik hastalık ve sistemik ilaç kullanımı hikayesi olmayan, 19-42 yaș arası 27 gönüllü bireyden kontrol grubu olușturuldu. Tüm gönüllü bireylerde de BCG așısı pozitifti. Hem hasta hem de kontrol grubundaki tüm hastalara PPD testi yapıldı.

Bulgular: Çalıșmamızın sonucunda Behçet hastalarının PPD testine verdiği yanıt kontrol grubuyla karșılaștırıldığında anlamlı derecede yüksek bulundu. PPD testine yüksek yanit verenlerin hiçbirinde aktif tüberküloz infeksiyonuna rastlanmadı.

Sonuç: PPD testinin Behçet hastalarında yüksek bulunması her zaman tüberküloz infeksiyonu olduğu anlamına gelmeyip yalancı pozitiflik olarak değerlendirilebilir. (Türkderm 2012; 46: 143-6)

Anahtar Kelimeler: Behçet hastalığı, tüberkülin deri testi, pürifiye protein derivesi

\section{Summary}

Background and Design: Both the alterations in the immune system and the presence of pathergy reaction in patients with Behçet's disease may lead to differences in the results of purified protein derivative (PPD) test reaction in these patients and healthy people. Materials and Methods: Twenty-one patients with Behçet's disease aged 19-44 years old were included in this study. None of these patients were using any systemic drug (except colchicum) and had any immunosuppressive disease. All patients were under colchicum treatment and all had had BCG vaccination. Control group was formed by 27 volunteers aged 19-42 years who have applied to our dermatology outpatient clinic on the same dates and were diagnosed as tinea pedis. None of them were using any immunosuppressive drug and had any immunosuppressive disease. All of them also had had BCG vaccination. PPD test was performed to both control and patient groups. Results: The results of PPD test were found higher in the patients with Behçet's disease compared to the control group. Active tuberculosis infection was not determined in any of the patients with increased PPD reaction.

Conclusion: Increased PPD test results in patients with Behçet's disease do not always imply tuberculosis infection and might be accepted as a false-positive result. (Turkderm 2012; 46: 143-6)

Key Words: Behçet's disease, tuberculin skin test, purified protein derivative

\section{Giriş}

Behçet hastalığı (BH) tekrarlayan oral aftlar, genital ülserler, üveit veya hipopiyonlu iridosiklit ve bunlara eşlik edebilen çeşitli deri lezyonları ile tanınan, remisyon ve alevlenmelerle seyreden, multisistemik, inflamatuvar bir vaskülittir1-3. Hastalığın etyolojisi ve patogenezi henüz kesin olarak bilinmemekle birlikte özellikle hücresel immünitenin aktivasyonu ile ilgili kanıtlar ortaya

Yazışma Adresi/Address for Correspondence: Dr. Evren Odyakmaz Demirsoy, Derince Eğitim ve Araștırma Hastanesi, Deri ve Zührevi Hastalıklar Kliniği, Kocaeli, Türkiye Tel.: +90 2623037262 E-posta: evrenodyakmaz@yahoo.com Geliş Tarihi/Received: 08.08.2011 Kabul Tarihi/Accepted: 31.10 .2011 
konmuştur. T hücre değişikliği özellikle Th1/Th2 oranında değişme şeklinde olup, sitokinler üzerinde yapılan çalışmalarda Th1 sitokinlerin etkisinin Behçet hastalarında ön planda olduğu düşünülmektedir ${ }^{4}$. Ayrıca İnterlökin (IL)-12 ve 18 gibi antijen sunan hücrelerden salınan sitokinlerin düzeyinde artış olması ve sağlıklı gönüllülerle karşılatırıldığında epidermal Langerhans hücrelerinin Behçet hastalarında daha aktif olması antijen sunan hücrelerin de $\mathrm{BH}$ patogenezinde önemli olduğu görüşünü desteklemektdir 5 . Deri ve mukoza tutulumu olan hastalarda tedavide genellikle kolşisin kullanılırken, diğer sistem tutulumu olan hastalarda sistemik steroidler ve immunsupresif ajanlar tedavide önemli yer tutmaktadırlar. Son zamanlarda biyolojik ajanlar da Behçet hastalığı tedavinde kullanılmaya başlanmıştır. İmmünsupressif ilaçlarla ya da biyolojik ajanlarla tedavi edilecek hastalarda ülkemizde hala bir sağlık problemi olan tüberküloz infeksiyonunun olmadığı gösterilmelidir6-8. Tüberküloz infeksiyonu tanısı için standart bir tanı yöntemi mevcut olmayıp PPD testi infeksiyonun belirlenmesinde hala en yaygın kullanılan testtir9,10.

Behçet hastalarında hem immun sistemdeki varolan değişiklikler hem de paterji reaksiyonu nedeniyle PPD testine yanıtın sağlıkı bireylerden daha farklı alınabileceğini, bu farklıı̆̆ın da immunsupresif tedavi planlanacak hastalarda önemli olabileceğini düşündük. Bu düşüncelerden yola çıkarak yaptığımız çalışmamızda Behçet hastaları ile sağlıklı gönüllülerin PPD değerlerini karşılaştırmayı amaçladık.

\section{Gereç ve Yöntem}

Bu deneysel çalışmaya 30.01.2007 tarih ve IAEK 2/13 sayılı etik kurul onayı alındıktan sonra Uluslararası Behçet Hastalığı Çalışma Grubu kriterlerine göre Behçet hastalığı tanısı konmuş, herhangi bir immünsüpresif ilaç (sistemik steroid, azatiyopürin, siklosporin ve/veya siklofosfamid) almayan, başka bir sistemik hastalığı ve kolşisin dışında sistemik ilaç kullanım öyküsü olmayan hastalar dahil edildi. Yirmi yaş altı ve 40 yaş üstü olan, immünsupressif tedavi alan, gebe ve emziren hastalar çalışmaya dahil edilmedi.

Yukarıdaki kriterlere uyan, 19-44 yaş arası 11 erkek ve 10 kadın, toplam 21 Behçet hastası ile çalışma grubu oluşturuldu. Tüm hastalar kolşisin tedavisi almaktaydı ve BCG aşıları pozitifti.

Dermatoloji polikliniğine başvuran ve tinea pedis tanısı konulan, herhangi bir sistemik hastalığı olmayan ve sistemik ilaç kullanmayan, 19-42 yaş arası

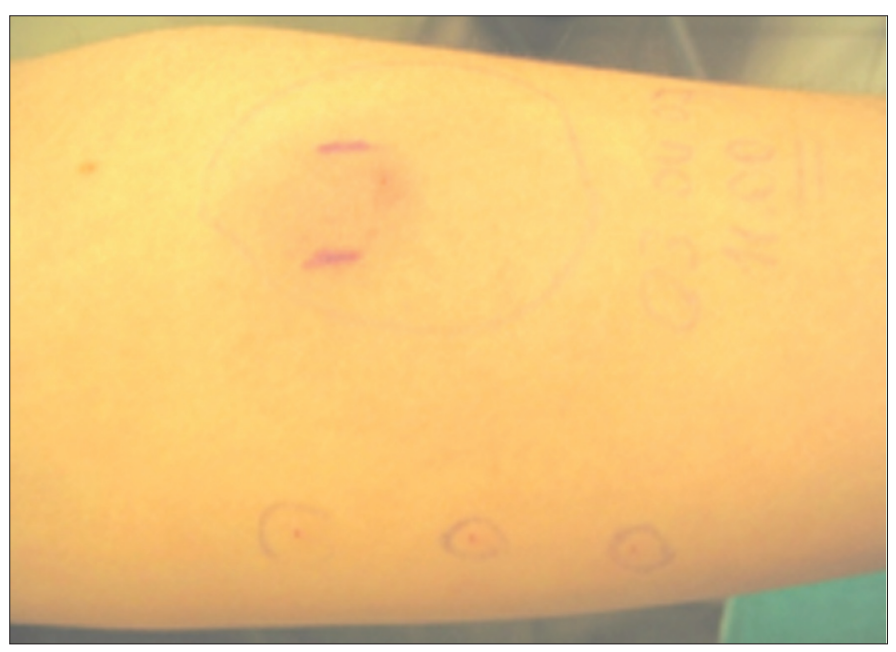

Resim 1. Behçet hastasında 15mm olarak ölçülen PPD testi ve paterji testi negatifliği
11 erkek ve 16 kadın, toplam 27 gönüllü bireyden kontrol grubu oluşturuldu. Tüm gönüllü bireylerin de BCG aşısı pozitifti.

Hem hasta hem de kontrol grubundaki tüm hastalardan, yazılı izinleri alındıktan sonra tüberkülin deri testi (TDT); PPD solüsyonu sol ön kolun 2/3 üst iç kısmına, mümkün olduğunca kılsız ve venlerden uzak bir bölgeye enjekte edilerek yapıldı. Solüsyonun 5 Tü'ye eşdeğer olan 0,1 ml'si insülin enjektörüyle (27 numaralı iğne) deri içine (intrakutan) 6-10 mm'lik beyaz renkli bir papül oluşturacak şekilde verildi. Sonuçlar 48.-72. saatlerde Kocaeli Üniversitesi Tıp Fakültesi Göğüs Hastalıkları Anabilimdalı'nda görev yapan bir doktor tarafından değerlendirildi. Test sonucunda test bölgesinde indürasyon oluşmadıysa sonuç "sıfır mm" olarak rapor edildi. PPD testinin değerlendirilmesi, T.C. Sağlık Bakanlığı Verem Savaşı Daire Başkanlığı tarafından belirlenmiş değerlendirme kriterlerine göre yapıldı. PPD değeri 15 mm'den büyük olan hastalar akciğer filmi çektirilerek Göğüs Hastalıkları polikliniğinde akciğer tüberkülozu açısından değerlendirildi.

Çalışma grubunu oluşturan Behçet hastalarına PPD testi ile eş zamanlı olarak PPD testinin uygulandığı alana mümkün olduğunca uzak olacak şekilde paterji testi de yapıldı. İşlem sırasında 20 numaralı steril bir iğne ucuyla hastaların ön kol fleksör yüzlerindeki deri 6 noktadan pikür yapılarak delindi. Bu test için iğnenin dermise inebilecek derinlikte ve 45 derecelik açı ile uygulanmasına özen gösterildi. Değerlendirmeler 24.-48. saatlerde yapıldı (Resim 1). Bu testi yaparken amaç PPD testinde aldığımız cevabın bir paterji reaksiyonu olup olmadığını anlayabilmek olduğu için sağlıklı gönüllü bireylere bu test uygulanmadı.

Elde edilen verilerin değerlendirilmesinde "SPSS (Statistical Package for Social Science) 13.0 for Windows Version" programı kullanıldı. Çalışma grubu ve kontrol grubuna ait olguların PPD sonuçları (sayısal veriler) Student-t testi kullanılarak birbiriyle karşılaştııılı. Gruplara göre cinsiyet dağılımı Chi-Square testi kullanılarak hesaplandı. İstatiksel karşılaştırmalar sonucunda $p<0,05$ değerleri anlamlı kabul edildi.

\section{Bulgular}

Çalışmaya 20-40 yaş arası 11 erkek ve 10 kadın Behçet hastası ve kontrol grubu olarak 11 erkek ve 16 kadın sağlıklı birey alındı. PPD testi yapılan kişilerin hiçbirinde beklenmeyen bir yan etki ile karşılaşılmadı.

Çalışmaya katılan Behçet hastaları ile kontrol grubunun yaş ve cinsiyet açııından karşılaştırılması istatiksel olarak yapıldı ve Behçet hastaları ile kontrol grubu arasında yaş ve cinsiyet açısından anlamlı bir fark saptanmadı.

72. saatte elde edilen PPD testi sonuçlarının aritmetik ortalaması Behçet hastalarında 13,1 $\pm 7,5$ olarak hesaplanırken kontrol grubunda $6,2 \pm 4,2$ olarak hesaplandı.

Behçet hastaları ile kontrol grubuna ait PPD sonuçları istatiksel olarak karşılaştırıldığında; Behçet hastalarında PPD değerleri kontrol grubuna göre anlamlı derecede daha yüksek bulundu $(p=0,000)$ (Tablo 1).

Tablo 1. Behçet hastaları ve kontrol grubunun cinsiyet, yaş ve PPD değerlerinin karşılaştırılması

\begin{tabular}{|l|c|c|c|}
\hline & $\begin{array}{c}\text { Behçet hastaları } \\
(\mathbf{n = 2 1 )}\end{array}$ & $\begin{array}{c}\text { Kontrol } \\
(\mathbf{n = 2 7})\end{array}$ & $\mathbf{p}$ \\
\hline Cinsiyet (kadın/erkek) & $10 / 11$ & $16 / 11$ & 0,348 \\
\hline Yaş (yıl) & $33,3 \pm 8,3$ & $31,3 \pm 6,5$ & 0,561 \\
\hline PPD (mm) & $13,1 \pm 7,5$ & $6,2 \pm 4,2$ & 0,000 \\
\hline
\end{tabular}


PPD değeri yüksek tespit edilen tüm hastalar Göğüs Hastalıkları polikliniğinde tüberküloz infeksiyonu açısından değerlendirildi. Bu hastaların hiçbirinde aktif veya geçirilmiş tüberküloz infeksiyonu düşündürecek herhangi bir bulguya rastlanmadı.

Çalışmaya dahil edilen tüm Behçet hastalarına PPD testi ile eş zamanlı yapılan paterji testi negatif olarak değerlendirildi. Bu durum hastaların kolşisin kullanıyor olmalarına bağlandı.

\section{Tartışma}

Behçet hastalığı ataklarla birlikte uzun süreli bir seyir gösteren, etyolojisi tam olarak bilinmeyen sistemik bir vaskulittir ${ }^{11}$. Paterji fenomeni, minör travma sonrası derinin nonspesifik hiperreaktivite reaksiyonudur. Behçet hastalarında paterji testi sıklıkla pozitiftir2,12 ve bu testin pozitifliği coğrafik farklılıklar göstermektedir. Türkiye, Japonya ve diğer Akdeniz ülkelerinde en yüksek oranda pozitiflik görülürken diğer ülkelerde bu oran daha azdır2,13. Bunlarla birlikte paterji testi BH için spesifik bir bulgu olmayıp sağlıklı bireylerde ve piyoderma gangrenozum, Sweet sendromu, eritema elevatum diutinum, romatoid artrit, rekürren aftöz stomatit, iridosiklit, idyopatik eritema nodozum, herpes genitalis gibi bazı inflamatuvar deri hastalıklarında da pozitif olabilir. Bu test BH için \%100 olmamakla beraber yine de yüksek derecede spesifik olduğundan hastalığın tanı kriterleri arasında yer almaktadır². Bu reaksiyonun oluşum mekanizmasında hücresel immünite rol oynamakla birlikte reaksiyonun başlangıcında tetik çekici olayın nötrofil kemotaksisi olduğu düşünülmektedir13-15.

Tüberküloz infeksiyonu ve hastalığı ülkemiz gibi gelişmekte olan ülkelerde hala sık karşılaşılan ciddi sağlık problemlerindendir16. Yaygın olarak kullanılan PPD testi, doğru uygulansa ve doğru yorumlansa bile yanlış negatif ve yanlış pozitif sonuçlar verebileceğinden tüberküloz infeksiyonu tanısı için tek başına yeterli değildir. Tüberküloz hastalığı tanısı beraberinde temas öyküsünün ve anlamlı klinik bulguların varlığı ile konulmaktadır9,10. Özellikle tüberküloz prevelansının yüksek olduğu ve ülkemiz gibi BCG aşısının rutin uygulandığı toplumlarda testin tüberküloz lehine yorumlanması yanlış olabilir. Buna karşın diğer parametreler ile birlikte yorumlandığında tüberküloz tanısı için hala anlamlı bir yere sahiptir 16 .

İmmun sistemde değişikliğe yol açan bir hastalık olan Behçet hastalığında paterji fenomeninin de etkisiyle TDT cevabında, normal bireylerle karşılaştırıldığında değişiklikler olabileceğini, eğer böyle bir değişiklik varsa da, bu durumun immunsupresif ilaçlar ve biyolojik ajanlarla tedavi planlanacak ve takipleri yapılacak hastalarda önemli olabileceğini düşündük. Behçet hastalarının ve kontrol grubunu oluşturan gönüllü bireylerin PPD ölçümleri karşılaştııılıklarında Behçet hastalarında PPD değerleri kontrol grubuna göre anlamlı derecede daha yüksek bulundu $(p=0,000)$. PPD değeri yüksek tespit edilen tüm hastalar Göğüs Hastalıkları polikliniğinde tüberküloz infeksiyonu açısından değerlendirildi, ancak hiçbir hastada aktif veya geçirilmiş tüberküloz infeksiyonu düşündürecek herhangi bir klinik bulguya rastlanmadı. Buna göre; PPD testinin Behçet hastalarında yüksek bulunmasının her zaman hastada tüberküloz infeksiyonu olduğu anlamına gelmeyebileceğini, bu durumun yalancı pozitiflik olarak değerlendirilebileceğini düşündük.

Bir intradermal test olan PPD testinin Behçet hastalarında bir çeşit paterji reaksiyonu olabileceği düşünülebilir. Ancak iki testin patogenezi birbirinden farklıdır. Paterji reaksiyonunun başlangıcında iğne ile oluşturulan travma nedeniyle nötrofil kemotaksisi uyarılır. Bundan sonra hücresel immünitenin devreye girmesi ile reaksiyon tamamlanır4,14. PPD testinde ise iğne ile oluşturulan travmayla beraber deri altına enjekte edilen bakteri antijenleri vardır ki bu antijenler direk olarak hücresel immünitenin uyarımasına neden olur. Çalışma grubumuzu oluşturan tüm hastalar nötrofil kemotaksisini inhibe ederek etki eden kolşisin tedavisi altında ve remisyon döneminde olan hastalardı. Kırksekizinci saatte yapılan paterji testi değerlendirmesi sonucu hastalarımızın hepsinde negatif olduğu halde PPD test sonuçları kontrol grubuna göre daha yüksek olarak bulundu ve PPD testi pozitifliğinin paterji reaksiyonuna bağlı olamayacağı düşünüldü. Behçet hastalarında CD4+/ CD8+ T hücre oranındaki ve fonksiyonundaki varolan değişiklikler ${ }^{11}$, antijen sunan hücrelerin sağlıklı gönüllülere göre daha aktif olması 5 bu hastalarda hücresel immün yanıtın farklı olmasına sebep olabilir. Hücresel immün yanıttaki bu değişiklik $\mathrm{BH}$ 'daki PPD testinde olan yalancı pozitifliği açıklayabilir.

Konuyla ilgili yaptığımız literatür taramasında 1982 yılına ait Japonya'da yapılmış bir çalışmada $\mathrm{BH}^{\prime}$ da intradermal testlere karşı artmış cevap olabileceğinin bildirildiğini gördük ${ }^{17}$. Pickering ve arkadaşları tüberküloz infeksiyonu olmamasına rağmen PPD pozitifliği gösteren bir hasta sunmuşlar ve bunun paterji reaksiyonuna bağlı olduğunu düşünmüşlerdir ${ }^{18}$

Hatemi ve arkadaşlarının yaptıkları bir çalışmada 80 Behçet hastası, 61 romatoid artritli hasta ve 38 sağlıklı gönüllüye PPD testi yapılmış ve bizim sonuçlarımızın aksine Behçet hastalarının PPD değerlerinin sağlıklı gönüllülerin PPD değerlerinden farklı olmadığı görülmüştür8. Yine bu çalışmada Behçet hastalarına paterji testi de yapılmış, paterji testi pozitif olanlar ile olmayanlar PPD değerleri açısından karşılaştırılmış ve aralarında anlamlı bir farklılık olmadığı görülmüştür. Yazarlar bu sonucu paterji pozitifliğinin PPD testi sonuçlarını değiştirmediği şeklinde yorumlamışlardır8. Tüberküloz basili ile daha önceden karşılaştığı bilinen kişilerin tüberkülin deri testine yanıt vermemelerine anerji denir ve bu durum ileri yaş, aşıı kilo kaybı, çok ağır veya yaygın tüberküloz infeksiyonu durumlarında görülebilir ${ }^{19}$. Behçet hastalarından 4 hastanın PPD sonucu anerjik olarak değerlendirildi. Bu durumun PPD testinin yapılış tekniği veya PPD solüsyonunun kendisi ile ilgili bir probleme bağlı olabileceğini ya da bilinen immünsupressif bir hastalık veya ilaç kullanım hikayesi olmayan hastalarımızın 4'ünde izlenen anerjik yanııı henüz tespit edilmemiş bir viral enfeksiyon veya stres gibi immünsupressif başka bir duruma bağlı gelişebileceğini düşündük.

Sonuç olarak çalışmamızda hücresel immünitenin hiperaktif olduğu Behçet hastalarında elde edilen yüksek PPD değerlerinin her zaman tüberküloz infeksiyonu anlamına gelmeyeceği, bu durumun yalancı pozitiflik olarak değerlendirilebileceği sonucuna vardık.

\section{Kaynaklar}

1. Özbalkan Z, Bilgen SA: Behçet Hastalı̆ı. Hacettepe Tıp Dergisi 2006;37:14-20.

2. Al-Otaibi LM, Porter SR, Poate TW: Behcet's disease: a review. J Dent Res 2005;84:209-22.

3. Pamuk ÖN, Çakır N: Behçet hastalığının epidemiyolojisi. Türkiye Klinikleri J Int Med Sci 2005;15:3-9.

4. Borlu M: Behçet hastalığında etyopatogenez. Sağlık Bilimleri Dergisi 2007;16:63-72.

5. Pay S, Simsek I, Erdem H, Dinc A: Immunopathogenesis of Behcet's disease with special emphasize on the possible role of antigen presenting cells. Rheumatol Int 2007;27:417-24.

6. Mat C: Behçet hastalığında tedavi. TURKDERM 2009;43(Ek:2):92-7.

7. Barnes CG: Treatment of Behcet's syndrome. Rheumatology (Oxford) 2006;45:245-7. 
8. Hatemi I, Hatemi G, Celik AF, et al: Frequency of pathergy phenomenon and other features of Behcet's syndrome among patients with inflammatory bowel disease. Clin Exp Rheumatol 2008;26:91-5.

9. Soysal A, Bakır M: Tüberküloz enfeksiyonunda tanı: Tübekülin Deri Testi. J Ped Inf 2007;1:27-32.

10. Ursavaş $A$, Karadağ M, Sağlam A, et al: Tüberküloz tanısında tüberkülin deri testinin güvenilirliği ve bazı parametreler ile ilişkisi. Uludağ Üniversitesi Tıp Fakültesi Dergisi 2004;30:11-5.

11. Akman A, Alpsoy E: Behçet hastalığı: Etyopatogenezde güncel bilgiler. TURKDERM 2009;43(Ek:2):32-8.

12. James DG: 'Silk route disease' (Behcet's disease). West J Med 1988;148:433-7.

13. Alpsoy E, Zouboulis CC, Ehrlich GE: Mucocutaneous lesions of Behcet's disease. Yonsei Med J 2007;48:573-85.
14. Pay S: Behçet hastalığı: Etyoloji ve patogenez. Türkiye Klinikleri J Int Med Sci 2005; 1:10-18

15. Hirohata S, Kikuchi H: Behcet's disease. Arthritis Res Ther 2003;5:139-46.

16. Kurt A, Poyrazoğlu $G$, Turgut $M$ ve ark: Tüberküloz tanısıyla izlenen hastaların klinik ve labaratuvar özellikleri. Fırat Tıp Dergisi 2006:55-57.

17. Isobe T, Matsumoto J, Tomita M, Itoh T, Fujita T, Takahashi T: Intradermal tests in Behcet's disease. Jpn J Med 1982;21:86-8.

18. Pickering MC, Haskard DO: False-positive results obtained using the Mantoux test in Behcet's syndrome: comment on the article by Garcia-Porrua et al. Arthritis Rheum 2000:43:2855-6.

19. Özkara Ş: Klinisyenler için tüberküloz klavuzu. Ankara: Nobel Tıp Kitabevi; 2002;67-96. 